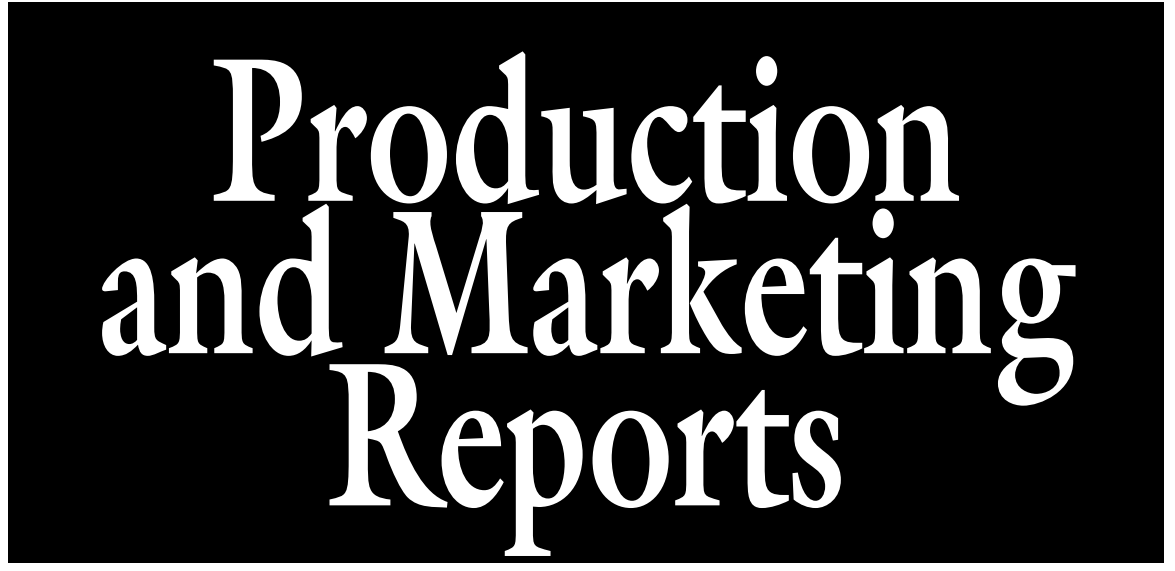

\section{Risk-rated Economic Return Analysis for Southern Highbush Blueberries in Soil in Georgia}

\author{
Esendugue Greg Fonsah ${ }^{1,5}$, Gerard Krewer ${ }^{2}$, Kerry Harrison $^{3}$, and \\ Michael Bruorton ${ }^{4}$
}

ADDITIONAL INDEX WORDS. production cost, harvesting, marketing, variable, and fixed costs

SUMMARY. Southern highbush blueberries (Vaccinium corymbosum $\times$ V. darrowii hybrids) are a rapidly emerging crop with a bright future in Georgia; however, blueberries, like other fruit crops, are subject to price and yield fluctuation. These volatilities depend on several factors, including the cultivar produced and sold (i.e., fresh or frozen), locality, aggregate productivity, targeted market, and timing. As a result, profit margin is hard to determine. The objective of this study was to estimate total costs of cultivating southern highbush blueberries in soil under Georgia conditions and determine profitability, if any. Although there are several methods of profit determination, the risk-rated method was adopted for this study. The first-year establishment and maintenance cost of growing southern highbush blueberry in soil in Georgia using high organic matter (greater than 3\%) spodic-type or allied sand soil series with supplemental pine bark incorporated was estimated at $\$ 9585.55 / a c r e$. The second-year establishment and maintenance cost of growing, harvesting, and marketing was $\$ 3691.99 /$ acre less return from receipts of $\$ 2375.00 /$ acre equal to $\$ 1316.99 /$ acre. The third-year establishment and maintenance cost was $\$ 7068.20 /$ acre. The total returns for the same year were $\$ 9500.00 /$ acre. Subtracting the cost of $\$ 7068.20$ from $\$ 9500.00$ gives a net return of $\$ 2431.80 /$ acre. The fourth-year cost, which was considered to be the first year of actual full production, was estimated at $\$ 13,547.35 /$ acre. The compounded and recaptured establishment annual costs were $\$ 2176.43 /$ acre. The risk-rated expected returns over total costs $66 \%$ of the time were $\$ 5452.65 /$ acre. The chances of making profit were $92 \%$ and the base-budgeted net revenue was $\$ 6456.00 /$ acre. Total budgeted cost was $\$ 3.38 / 1 \mathrm{~b}$. The estimated annual total fixed machinery cost was $\$ 290.41 /$ acre. Total annual cost of solid set irrigation was $\$ 657.81 /$ acre.
S outhern highbush blueberries have become an important fruit crop in Georgia. They ripen much earlier than the rabbiteye blueberry (Vaccinium ashei) during a potentially lucrative market window in April and May in southern Georgia, but have exacting cultural requirements. They are considered by experienced farmers to be a challenging crop to grow. Soil conditions for good growth must be moist but very well drained. Several insects and diseases attack the plants and constant vigil is needed to keep pests at bay (Payne et al., 1993; Smith, 2003; Steck and Payne, 1993).

Most southern highbush blueberries bloom early. Overhead irrigation normally is used for spring freeze protection. These systems work well during most freezes with little or no wind (radiation freezes). However, most of these systems are not designed to protect during freezes with significant wind (advective freezes) (Krewer and NeSmith, 2002). Three methods of southern highbush culture have been commercially successful: 1) planting in pine bark beds $\approx 6$ to 8 inches deep with overhead irrigation, 2) planting in high organic matter (greater than $3 \%)$ spodic-type or allied sand soil series, and 3) planting in sand or loamy sand soils and amending the soil with pine bark in the row. This article is directed toward methods two and three.

Overhead (sprinkler) irrigation is necessary when pine bark alone is used as a growing substrate and recommended when pine bark is incorporated in the soil, because water does not move well laterally in pine bark. Two rows of drip tape on each bed could also be used in place of overhead irrigation; however, drip
We thank the Southern Region Small Fruit Consortium for providing funding for this research. We appreciate Drs. D.S. NeSmith, M. Rieger, P. Bannen, C. Escalante, and C. Lacy for their review and insightful comments. Finally, thanks to A.H. Pitts for all her contributions before and during the submission process.

${ }^{1}$ Department of Agriculture and Applied Economics, University of Georgia, 15 RDC Road, P.O. 1209, Tifton, GA 31793

${ }^{2}$ Department of Horticulture, University of Georgia, Tifton, GA 31793

${ }^{3}$ Biological and Ag Engineering Department, University of Georgia, Tifton, GA 31793

${ }^{4}$ Clinch County Extension Service, University of Georgia, Tifton, GA

${ }^{5}$ Corresponding author. E-mail: gfonsah@uga.edu.

\begin{tabular}{llll}
\hline $\begin{array}{l}\text { Units } \\
\text { To convert U.S. to SI, } \\
\text { multiply by }\end{array}$ & U.S. unit & SI unit & $\begin{array}{l}\text { To convert SI to U.S., } \\
\text { multiply by }\end{array}$ \\
\hline 0.4047 & acre(s) & $\mathrm{ha}$ & 2.4711 \\
29.5735 & $\mathrm{fl} \mathrm{oz}$ & $\mathrm{mL}$ & 0.0338 \\
0.3048 & $\mathrm{ft}$ & $\mathrm{m}$ & 3.2808 \\
3.7854 & gal & $\mathrm{L}$ & 0.2642 \\
0.7457 & horsepower & $\mathrm{kW}$ & 1.3410 \\
2.5400 & inch(es) & $\mathrm{cm}$ & 0.3937 \\
0.4536 & $\mathrm{lb}$ & $\mathrm{kg}$ & 2.2046 \\
1.1209 & $\mathrm{lb} / \mathrm{acre}$ & $\mathrm{kg} \cdot \mathrm{ha}^{-1}$ & 0.8922 \\
28.3495 & $\mathrm{oz}$ & $\mathrm{g}$ & 0.0353 \\
0.4732 & $\mathrm{pt}$ & $\mathrm{L}$ & 2.1134 \\
0.9464 & $\mathrm{qt}$ & $\mathrm{L}$ & 1.0567 \\
0.7646 & yard & $\mathrm{m}^{3}$ & 1.3080
\end{tabular}

Horfechnology · October-December 2007 17(4) 
irrigation provides minimal protection during a freeze. In addition, overhead irrigation is very useful to activate fertilizers and preemergent herbicides. The wetting and drying cycle characteristic in overhead irrigation is also thought to reduce conditions favorable for phytophthora root rot (Phytophthora cinnamoni), a primary killer of southern highbush blueberries that has a swimming spore phase. Drip irrigation offers the advantage of low-cost installation, operation, and fertigation. Growers often use drip irrigation during the establishment phase and switch to overhead irrigation later (Krewer and NeSmith, 2002); however, only the overhead irrigation system was incorporated in this study.

\section{Materials and methods}

Rabbiteye and southern highbush blueberry budgets developed by Westberry et al. (1995), Cline and Mainland (1999), and Lisec et al. (1995) were used as a starting point for developing this budget. Hundreds of farm visits and many interviews with growers were conducted to study southern highbush blueberry operations and collect the necessary primary data needed to estimate cost of production and obtain information into the type and cost of current practices in southern highbush blueberry culture. Several extension agricultural economists, horticulturists, agricultural engineers, and county extension agents were visited and interviewed to gather agronomic, irrigation, and equipment data required for this estimate. Vendors of agricultural inputs (fertilizers, chemicals, and equipment) were contacted to obtain current prices needed to generate variable and fixed costs components concomitantly. Numerous publications were consulted to obtain historical information on productivity, marketing, price, and overall outlook of southern highbush blueberries (Abbe and Messer, 2002; Pollack and Perez, 2003). The objective of this research was to estimate the cost of production, to project profit margin, and to analyze investment alternatives using risk-rated return. The budget was developed using what is considered to be the typical number of pesticide applications and amounts of pine bark required on moderately good southern highbush soils in the Flatwoods Region of southern Georgia. Chemical use and application were based on the recommendations of the University of Georgia extension specialists.

A risk-rated method was used to calculate expected returns. The riskrated method assigns five categories of yield and price per pound of southern highbush blueberry, thus "best," "optimistic," "median," "pessimistic," and "worst." Risk-rated returns over total costs were calculated by assigning probabilities or chances of occurrences to each of the categories (Brigham, 1982). Then the percentage chances of profit and the base-budgeted net revenue were calculated. Additionally, all variable and fixed-costs components were captured. Various cost components included preplant and preemergence weed control, planting and transplanter, land preparation, and pest and disease control. In other words, variable costs included preharvest, harvesting, and marketing costs, respectively, whereas fixed costs included machinery, irrigation, recaptured establishment costs, depreciation, taxes, insurance, overhead, and management. As a result of the variability in the cost of land in southern Georgia, we purposively excluded cost of land in our calculations, although this is an opportunity cost accrued by the grower.

\section{Assumptions}

The risk-rated return assumes five different yields and prices per pound at the top of the budget, namely "best," "optimistic," "median," "pessimistic," and "worst." The "best" and "worst" yield or price levels were expected to occur once in at least 10 years. The "median" yield and price level were expected $50 \%$ of the time. The "optimistic" level would be surpassed $\approx 1$ year in 6 years, whereas the "pessimistic" level would occur 1 year in 6 years.

It was assumed that full production was reached in the fourth year. Plant spacing was $4 \times 10 \mathrm{ft}$. Variable interest rates of $6.25 \%$ of total operating/ variable costs were used for each year. Packaging cost per flat was based on custom picking. Hired-used labor was contracted at a flat rate of $\$ 7.00 / \mathrm{h}$. Harvest yields were calculated based on $95 \%$ fruit recovery rate, thus $5 \%$ field and packaging loss. Brokerage fee was $15 \%$ but it included cooling and handling. Overhead and management fee was $15 \%$ of total operating/variable cost. Compounded recaptured costs were based on $6 \%$ fixed interest rate and the expected lifespan of the southern highbush blueberry-planted field under Georgia conditions was 20 years. Machinery and equipment operating costs calculations were based on 50 acres. This is because the equipment, except for the frost protection irrigation system, can be distributed over more than 4 acres. The fixed interest rate used was $7 \%$.

All the calculations included such items as percentage use for crop, purchase price, salvage value, lifespan, depreciation, interest, tax, and insurance. All equipment was assumed to be new. Solid set irrigation was calculated based on 4 acres because that was the average farm size for new entrants. An irrigation sprinkler spacing of $40 \times 45 \mathrm{ft}$ and an 8 -inch-diameter well that is capable of pumping $\approx 600$ $\mathrm{gal} / \mathrm{min}$ (125 gal/min per acre) were used. Risk-rated marketing prices and yields were obtained from growers and the Michigan Blueberry Growers Marketing Inc. (D. Wheeler, personal communication). whereas input and equipment prices were obtained from vendor and machinery dealers, respectively. The adopted variable interest rates for operating/variable costs were for the short-term loans, whereas the fixed interest rates used for fixed, machinery, and compounded establishment costs were for the long-term loans.

FARM INPUT PRICES. There were several factors that can influence price of inputs, total cost of production, and profit margin. Many farmers in Georgia need not invest in overhead irrigation materials or dig a new well because they already have them available. If so, that would significantly increase profitability. Also, motor sizes (horsepower) were different depending on acreage. Quantity discounts for items such as packing supplies were factors that affected price of inputs. The cost estimate in this budget reflects a combination of the current agricultural practices in Georgia and recommendations from University of Georgia specialists. The prices were actual prices from vendors around the counties involved in blueberry production and they excluded quantity discounts.

ESTIMATED ANNUAL TOTAL FIXED MACHINERY COSTS. The fixed cost for the machinery included estimates 
for sprayers, rotary mower, wagons, tractor, hedger, truck, spreader, mulcher, harrow, and $\mathrm{V}$ blade (Table 1). These costs were calculated using the University of Georgia Agriculture Engineering and Economics calculations.

COMPOUNDED AND RECAPTURED ESTABLISHMENT COSTS. The total establishment costs for years 1,2 , and 3 were \$9585.55/acre, \$3691.99/ acre, and $\$ 7068.20 /$ acre, respectively. The fixed compounded interest rate was $6 \%$. We used 20 years in our calculations because we believe that a well-managed southern highbush blueberry farm with new cultivars such as 'Star' would last that long before it would need to be replanted. This is considered to be an optimistic lifespan, because old cultivars of southern highbush blueberry have only lasted for 10 to 15 years before the field needed replanting. The annual recapture establishment cost was \$2176.43/acre (Table 2).

Solid SET IRRIGATION COST. The annual fixed cost of irrigation per acre was estimated at $\$ 657.81$ /acre and includes pipe and fittings, sprinklers, 8 -inch-diameter well that can handle $600 \mathrm{gal} / \mathrm{min}$, pump, motor, installation, and miscellaneous expenses. This cost is considered fixed cost items. The variable/operating cost component of the solid set irrigation was $\$ 284.81 /$ acre. This calculation was based on 4 acres and sprinklers were $40 \times 45 \mathrm{ft}$ spacing, a 50 -horsepower motor size, and an irrigation rate of $125 \mathrm{gal} / \mathrm{min}$ per acre. The cost would have been extremely high if only $\mathrm{l}$ acre was used. For instance, the total annual fixed cost per 4 acres was $\$ 2632.00$, whereas the total annual fixed cost was $\$ 657.81 /$ acre, thus reflecting one-fourth of 4 acres. Total irrigation operating/variable cost was $\$ 284.81$ /acre, whereas total annual fixed and operating costs were $\$ 942.62$ /acre. Although the solid set system is relatively more expensive in terms of initial investment per acre, it is necessary for spring frost and freeze control (Brown and Skinner, 1980) (Table 3).

\section{Results and discussions}

The following sections provide a detailed discussion of the estimated establishment and maintenance costs to be incurred in each production year.

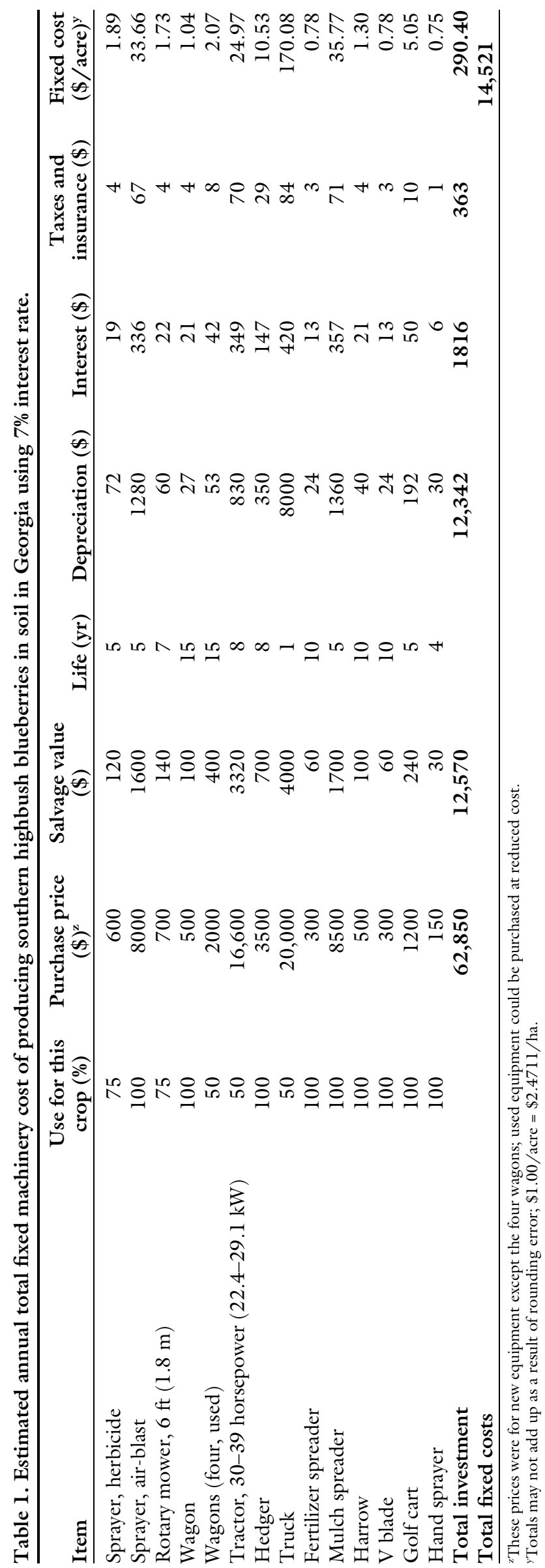


Table 2. Recaptured establishment cost per acre of producing southern highbush blueberries in soil in Georgia compounded for 20 years at $6 \%$ interest rate.

\begin{tabular}{|c|c|c|c|c|}
\hline & $\begin{array}{c}\text { Time to } \\
\text { production }(y \mathbf{r})\end{array}$ & $\begin{array}{c}\text { Compounded interest } \\
\text { rate (\%) }\end{array}$ & $\begin{array}{l}\text { Preestablishment } \\
\text { costs }(\$)\end{array}$ & Total $^{\mathrm{z}}(\$)$ \\
\hline & 3 & 1.1910 & $9,585.55$ & $11,416.39$ \\
\hline & 1 & 1.0600 & $7,068.20$ & $7,492.29$ \\
\hline Compounded establishment cost & & & & $23,057.00$ \\
\hline \multicolumn{4}{|c|}{ Recaptured annual establishment cost $(\$ / \text { acre })^{\mathrm{y}}$} & $2,176.43$ \\
\hline
\end{tabular}

${ }^{\mathrm{z}}$ Totals may not add up as a result of rounding error.

${ }^{\mathrm{y}} \$ 1.00 /$ acre $=\$ 2.4711 / \mathrm{ha}$.

\section{Estimated establishment and maintenance}

YeAR 1. The total operating/ variable cost of growing southern highbush blueberry in soil in Georgia was estimated at $\$ 7510.72 /$ acre. The total fixed cost was estimated at $\$ 2074.83$. Therefore, the total estimated establishment and maintenance cost for the first year was $\$ 9585.55$ (Table 4). The planting distance used in this risk-rated return was $4 \times 10 \mathrm{ft}$, equivalent to 1089 plants/acre costing $\$ 2123.55$. Other expensive cost components in land preparation operation were: 1) stumping, pushing stumps and large limbs, and burning, which costs $\$ 750.00 /$ acre depending on the number of stumps; 2) chopping small trees and brush with a drum roller, which costs $\$ 120 /$ acre; and 3) milled pine bark, which costs $\$ 2254.00$ for 322 yard $^{3}$. Fertility and both pre- and postemergence weed control cost were $\$ 231.34 /$ acre, whereas pest and disease control costs were $\$ 897.47 /$ acre (Table 4).

YEAR 2. In year 2, sprays for phytophthora root rot, mummy berry (Monilinia vacciniicorymbosi), leaf spot (Septoria albopuncata, Colletotrichum gloeosporioides, and Gloeosporium minus), and other pest and disease control contributed heavily to the variable/operating cost. Weed control and irrigation had a major impact on the total variable cost. The total variable cost was $\$ 1481.31 /$ acre, which is five times lower than year 1 . It was assumed that $500 \mathrm{lb}$ would be harvested in year 2 , equivalent to 145 flats (containing 12 containers of $125 \mathrm{~g}$ each) with a $95 \%$ packout rate.

Total harvesting and marketing costs were $\$ 1040.25 /$ acre. This includes harvesting, custom packing, cooling, handling, and brokerage fees, respectively. The fixed costs for the machinery included tractor and equipment, overhead irrigation, depreciation, taxes, insurance, interest, and management and were $\$ 1170.42 /$ acre. Total cost for year 2 was $\$ 3691.99 /$ acre. Assuming a return from receipts of $475 \mathrm{lb}$ with a $95 \%$ packout rate and a selling price of $\$ 5.00 / \mathrm{lb}$, gross receipts were $\$ 2375.00 /$ acre. This reduced the

Table 3. Estimated cost per acre of solid set irrigation/freeze protection for producing southern highbush blueberry in soil in Georgia based on 4 acres $(1.6 \mathrm{ha})$ with a $40 \times 45-\mathrm{ft}(12.2 \times 13.7 \mathrm{~m})$ spacing and a 50 -horsepower $(37.3 \mathrm{~kW})$ electric motor.

\begin{tabular}{|c|c|c|c|c|c|}
\hline Investment and annual fixed costs & $\begin{array}{l}\text { New cost } \\
(\$ / \text { acre })^{z}\end{array}$ & Life $(y \mathbf{r})$ & $\begin{array}{c}\text { Annual } \\
\text { depreciation } \\
(\$ / \text { acre })\end{array}$ & $\begin{array}{c}\text { Annual interest } \\
(\$ / \text { acre })\end{array}$ & $\begin{array}{l}\text { Annual taxes } \\
\text { and insurance } \\
(\$ / \text { acre })^{\mathrm{y}}\end{array}$ \\
\hline Pipe and fittings & 3840 & 20 & 192 & 134 & 29.00 \\
\hline Sprinklers & 960 & 10 & 96 & 34 & 7.00 \\
\hline Well, 8 inches $(20.3 \mathrm{~cm}), 600 \mathrm{gal} / \mathrm{min}\left(37.9 \mathrm{~L} \cdot \mathrm{s}^{-1}\right)$ & 10,500 & 25 & 420 & 368 & 79.00 \\
\hline Pump and motor & 10,500 & 15 & 700 & 368 & 79.00 \\
\hline Total investment & 26,900 & & 1488 & 943 & 203.00 \\
\hline Total annual fixed costs $(\$)$ & & $2,631.00$ & & & \\
\hline Annual fixed costs (\$/acre) & & 657.81 & & & \\
\hline \multicolumn{6}{|l|}{ Operating costs } \\
\hline Repairs (\$) & & 301 & & & \\
\hline Annual pumping time $(\mathrm{h})$ & & 80 & & & \\
\hline Annual energy costs $(\$)$ & & 839 & & & \\
\hline Annual energy costs (\$/acre) & & & & & 209.68 \\
\hline Operating cost per year ( $\$ /$ acre $)$ & & & & & 284.81 \\
\hline Total annual costs $(\$ /$ acre $)$ & & & & & 942.62 \\
\hline
\end{tabular}

${ }^{\mathrm{z}} \$ 1.00 /$ acre $=\$ 2.4711 / \mathrm{ha}$.

yTotals may not add up as a result of rounding errors. 
Table 4. Estimated first-year establishment and maintenance cost per acre of producing southern highbush blueberries in soil in Georgia.

\begin{tabular}{|c|c|c|c|c|c|}
\hline Items & $\begin{array}{c}\text { Applications } \\
\text { (no./yr) }\end{array}$ & $\begin{array}{c}\text { Unit of } \\
\text { application }^{\mathrm{z}}\end{array}$ & $\begin{array}{l}\text { Quantity of } \\
\text { application } \\
\text { (units/yr) }\end{array}$ & $\begin{array}{c}\text { Price per } \\
\text { application } \\
(\$ / \text { unit per } y r)\end{array}$ & $\begin{array}{c}\text { Total cost } \\
(\$ / \text { acre per } y r)^{y}\end{array}$ \\
\hline \multicolumn{6}{|l|}{ Land preparation ${ }^{\mathrm{x}}$} \\
\hline Preplant weed control & & gal & 2.50 & 36.00 & 90.00 \\
\hline Stumping, pushing, burning ${ }^{w}$ & & acre & 1.00 & 750.00 & 750.00 \\
\hline Chopping & & acre & 3.00 & 40.00 & 120.00 \\
\hline Bedding & & acre & 1.00 & 45.00 & 45.00 \\
\hline Breaking aisles & & acre & 1.00 & 30.00 & 30.00 \\
\hline Ditching and drainage & & acre & 1.00 & 80.00 & 80.00 \\
\hline Milled pine bark & & $\operatorname{yard}^{3}$ & 322.00 & 7.00 & 2254.00 \\
\hline \multicolumn{6}{|l|}{ Planting } \\
\hline Plants $4 \times 10 \mathrm{ft}(1.2 \times 3.0 \mathrm{~m})$ & & acre & 1089.00 & 1.95 & 2123.55 \\
\hline Fertilizer $(10 \mathrm{~N}-4.4 \mathrm{P}-8.3 \mathrm{~K})$ & 8 & $\mathrm{lb}$ & 545.00 & 0.12 & 65.40 \\
\hline Labor & 8 & $\mathrm{~h}$ & 8.00 & 7.00 & 56.00 \\
\hline \multicolumn{6}{|l|}{ Weed control } \\
\hline Preemergence & 1 & $\mathrm{qt}$ & 0.81 & 71.53 & 57.94 \\
\hline Glyphosate & 4 & $\mathrm{pt}$ & 0.50 & 90.00 & 45.00 \\
\hline Labor & 1 & acre & 1.00 & 7.00 & 7.00 \\
\hline \multicolumn{6}{|l|}{ Pest and disease control ${ }^{v}$} \\
\hline Insecticide & 3 & $\mathrm{lb}$ & 5.25 & 7.19 & 37.75 \\
\hline Fungicides (leaf spot) & 3 & $\mathrm{OZ}$ & 46.20 & 1.80 & 83.16 \\
\hline Fungicide (phytophthora root rot) & 2 & pt & 8.80 & 87.45 & 769.56 \\
\hline Labor (air-blast) & 4 & acre & 1.00 & 7.00 & 7.00 \\
\hline Pruning & & $\mathrm{h}$ & 3.00 & 7.00 & 21.00 \\
\hline Land $^{\mathrm{u}}$ & & $\$$ & 1.00 & 0.00 & 0.00 \\
\hline Others & & & 0.00 & 0.00 & 0.00 \\
\hline Total fixed costs & & & & & 2074.83 \\
\hline Total establishment costs & & & & & 9585.55 \\
\hline
\end{tabular}

total establishment cost in year 2 to $\$ 1316.99$ /acre (Table 5).

YeAR 3. In year 3, phytophthora root rot control was the largest variable cost component, $\$ 384.78$, equivalent to $22.3 \%$ of total variable/ operating cost/acre. However, overall pest and disease control contributed to over $48.6 \%$ of total variable cost, equivalent to $\$ 837.94 /$ acre. Pruning cost was $\$ 175.00 /$ acre, representing $\approx 10.2 \%$ of total variable cost. Actual chemical used for weed control cost
$\$ 125.40 /$ acre or $7.3 \%$ of total variable cost. Fertilizer cost was \$108.00/ acre, whereas irrigation use was $\$ 284.81 /$ acre.

Total harvesting and marketing costs was $\$ 4137.88 /$ acre. This included harvesting, custom packing, cooling, handling, and brokerage fees. The fixed costs for the machinery were $\$ 1206.76 /$ acre. Total cost for year 3 was $\$ 7068.20 /$ acre. Assuming a return from receipts of $1900 \mathrm{lbs}$ with a $95 \%$ packout rate and a selling price of $\$ 5.00 / \mathrm{lb}$, gross receipts were $\$ 9500.00 /$ acre. The historical price in this window has been $\$ 5.00 / \mathrm{lb}$ but is expected to decline with increased production. This minus the actual total cost of $\$ 7068.20 /$ acre equals a net gain of $\$ 2431.80 /$ acre in year 3 (Table 6).

\section{Full production cost}

YEAR 4. In the fourth year, the blueberry field is assumed to be in full production. Phytophthora root 
Table 5. Estimated second-year establishment and maintenance cost per acre of producing southern highbush blueberries in soil in Georgia.

\begin{tabular}{|c|c|c|c|c|c|}
\hline Items & $\begin{array}{c}\text { Applications } \\
\text { (no./yr) }\end{array}$ & $\begin{array}{c}\text { Unit of } \\
\text { application }^{z}\end{array}$ & $\begin{array}{l}\text { Quantity of } \\
\text { application } \\
\text { (units/yr) }\end{array}$ & $\begin{array}{c}\text { Price per } \\
\text { application } \\
(\$ / \text { unit per } y r)\end{array}$ & $\begin{array}{c}\text { Total cost } \\
(\$ / \text { acre per } y r)^{y}\end{array}$ \\
\hline \multicolumn{6}{|l|}{ Variable/operating costs } \\
\hline Fertilizer $(10 \mathrm{~N}-4.4 \mathrm{P}-8.3 \mathrm{~K})$ & 7 & $\mathrm{lb}$ & 225.00 & 0.12 & 27.00 \\
\hline Labor & 7 & $\mathrm{~h}$ & 7.00 & 7.00 & 49.00 \\
\hline Glyphosate/glufosinate & 6 & $\mathrm{pt}$ & 0.75 & 90.00 & 67.50 \\
\hline Labor & 1 & acre & 1.00 & 7.00 & 7.00 \\
\hline \multicolumn{6}{|l|}{ Pest and disease control ${ }^{\mathrm{x}}$} \\
\hline Insecticide & 3 & $\mathrm{lb}$ & 5.25 & 7.19 & 37.75 \\
\hline Mummyberry (if present) & 3 & $\mathrm{lb}$ & 15.00 & 5.15 & 77.25 \\
\hline Fungicide & 3 & $\mathrm{fl} \mathrm{oz}$ & 6.00 & 6.50 & 39.00 \\
\hline Fruit rot & 3 & $\mathrm{fl} \mathrm{oz}$ & 46.20 & 1.80 & 83.16 \\
\hline Labor (air-blast) & 6 & acre & 6.00 & 7.00 & 42.00 \\
\hline Pruning & 1 & $\mathrm{~h}$ & 3.00 & 7.00 & 21.00 \\
\hline Irrigation & & acre & 1.00 & 284.81 & 284.81 \\
\hline Interest on operating costs & & $\$$ & 1394.18 & 0.0625 & 87.14 \\
\hline Total variable/operating costs & & & & & 1481.31 \\
\hline \multicolumn{6}{|l|}{ Harvesting and marketing costs } \\
\hline Harvesting ${ }^{\mathrm{w}}$ & & $\mathrm{lb}$ & 500.00 & 0.50 & 250.00 \\
\hline Custom packing (clamshell container) & & flat & 145.00 & 2.75 & 398.75 \\
\hline Cooling, handling and brokerage (15\%) & & & 145.00 & 18.00 & 391.50 \\
\hline Total harvesting and marketing costs & & & & & 1040.25 \\
\hline \multicolumn{6}{|c|}{ Total operating, harvesting, and marketing costs Fixed costs } \\
\hline Total establishment costs & & & & & 3691.99 \\
\hline Less return from receipts & & & 475.00 & 5.00 & 2375.00 \\
\hline Total establishment cost & & & & & 1316.99 \\
\hline
\end{tabular}

${ }^{\mathrm{z}} \mathrm{l} \mathrm{lb}=0.4536 \mathrm{~kg} ; \mathrm{l} \mathrm{qt}=0.9464 \mathrm{~L} ; \mathrm{l} \mathrm{pt}=0.4732 \mathrm{~L} ; \mathrm{l}$ acre $=0.4047 \mathrm{ha} ; \mathrm{l} \mathrm{fl} \mathrm{oz}=29.5735 \mathrm{~mL} ; \mathrm{l} \mathrm{flat}=1.5 \mathrm{~kg}(3.31 \mathrm{lb})$.

'Totals may not add up as a result of rounding error; $\$ 1.00 /$ acre $=\$ 2.4711 /$ ha.

'Mummyberry (Monilinia vacciniicorymbosi), phytophtora root rot (Phytophthora cinnamoni), leaf spot (Septoria albopuncata, Colletotrichum gloeosporioides, Gloeosporium minus), botrytis (Botrytis cinerea), fruit rot (Alternaria tenuissima and Colletotrichum gloeosporioides).

"We assumed $95 \%$ packout rate.

${ }^{v}$ A typical price per acre varies significantly. Annual leasing price often range from $\$ 60 /$ acre to $\$ 100 /$ acre.

rot control was still the largest variable cost component, $\$ 384.78 /$ acre, equivalent to $18.4 \%$ of total variable cost. Actual chemicals for pest and disease control contributed to $39.1 \%$ of total variable cost, equivalent to $\$ 817.09 /$ acre. Actual pruning cost was estimated at $\$ 217.00 /$ acre, representing $\approx 10.4 \%$ of total variable cost. Overall actual preemergent and postemergent herbicide costs were $\$ 226.24$ /acre or $10.8 \%$ of total variable cost. Fertilizer cost was $\$ 127.00 /$ acre, whereas operating cost of irrigation use was \$284.81/ acre. Total harvesting and marketing costs were $\$ 8016.67 /$ acre. This included harvesting, custom packing, cooling, handling, and brokerage fees, respectively. The fixed costs of machinery were $\$ 3438.48 /$ acre. Total cost during this first full production year was $\$ 13,547.35 /$ acre. Assuming a return from receipts of $4000 \mathrm{lb}$ with a $95 \%$ packout rate and a selling price of $\$ 5.00 / \mathrm{lb}$, gross receipts would be $\$ 19,000.00 /$ acre. This minus the actual total cost of
$\$ 13,547.35 /$ acre equals a net gain of $\$ 5452.65 /$ acre in year 4 (Table 7 ).

Risk-rated returns over total costs

Table 8 shows the probabilistic chances of obtaining the various calculated risk-rated net return over total costs. The "Returns" row of Table 8 depicts seven different net return possibilities. According to Westberry et al. (1995), "all net returns are determined from their relationship to the expected net return." They are not determined by 
Table 6. Estimated third-year establishment and maintenance cost per acre of producing southern highbush blueberries in soil in Georgia.

\begin{tabular}{|c|c|c|c|c|c|}
\hline Items & $\begin{array}{c}\text { Applications } \\
\text { (no./yr) }\end{array}$ & $\begin{array}{c}\text { Unit of } \\
\text { application }^{z}\end{array}$ & $\begin{array}{l}\text { Quantity of } \\
\text { application } \\
\text { (units/yr) }\end{array}$ & $\begin{array}{c}\text { Price per } \\
\text { application } \\
(\$ / \text { unit per } y r)\end{array}$ & $\begin{array}{c}\text { Total cost } \\
(\$ / \text { acre per } y r)^{y} \\
\end{array}$ \\
\hline \multicolumn{6}{|l|}{ Fertilizers } \\
\hline Fertilizer (10N-4.4P-8.3K) & 5 & $\mathrm{lb}$ & 900.00 & 0.12 & 108.00 \\
\hline Labor & 5 & $\mathrm{~h}$ & 5.00 & 7.00 & 35.00 \\
\hline Glyphosate/glufosinate & 6 & pt & 0.75 & 90.00 & 67.50 \\
\hline Labor & 1 & acre & 1.00 & 7.00 & 7.00 \\
\hline Pest and disease control ${ }^{\mathrm{x}}$ & & & & & 0.00 \\
\hline Insecticide treatment & 3 & $\mathrm{lb}$ & 5.25 & 7.19 & 37.75 \\
\hline Mummyberry treatment & 3 & $\mathrm{lb}$ & 15.00 & 5.15 & 77.25 \\
\hline Fungicide control & 3 & $\mathrm{Oz}$ & 6.00 & 6.50 & 39.00 \\
\hline Fruit rot treatment & 3 & $\mathrm{fl} \mathrm{oz}$ & 46.20 & 1.80 & 83.16 \\
\hline Labor (air-blast) sprayer & 7 & acre & 7.00 & 7.00 & 49.00 \\
\hline Pruning & 1 & $\mathrm{~h}$ & 25.00 & 7.00 & 175.00 \\
\hline Irrigation & & acre & 1.00 & 284.81 & 284.81 \\
\hline Interest on operating costs & & $\$$ & 1622.18 & 0.0625 & 101.39 \\
\hline Total operating costs & & & & & 1723.56 \\
\hline \multicolumn{6}{|l|}{ Harvesting and marketing costs } \\
\hline Harvesting ${ }^{\mathrm{w}}$ & & $\mathrm{lb}$ & 2000.00 & 0.50 & 1000.00 \\
\hline Custom packing (clamshell container) & & flat & 575.76 & 2.75 & 1583.33 \\
\hline Cooling, handling, and brokerage (15\%) & & $\$$ & 575.76 & 18.00 & 1554.55 \\
\hline Total harvesting and marketing costs & & & & & 4137.88 \\
\hline Total variable, harvesting, and marketing costs & & & & 5861.44 & \\
\hline Total net returns (\$/acre) & & & & & 2431.80 \\
\hline
\end{tabular}

multiplying prices and yields and subtracting total cost. Rather, they reflect the variability of prices and yields. The first "Chances" row shows the estimated frequency of obtaining the previously mentioned net returns or more. The second "Chances" row shows the estimated frequency of obtaining these net returns or less.

For instance, there were only $6 \%$ chances of obtaining $\$ 15,140.00 /$ acre of southern highbush blueberry in soil in Georgia, whereas there were $7 \%$ chances of earning a negative return $-\$ 474.00 /$ acre. Furthermore, there were $66 \%$ chances of earning the expected $\$ 5456.00 /$ acre. The risk- rated return over total costs further depicted that the base-budgeted net revenue was $\$ 6456.00 /$ acre with a $92 \%$ chance of making profit under Georgia conditions (Table 8).

\section{Conclusion}

The preharvest variable cost in this risk-rated return analysis was $\$ 0.52 / \mathrm{lb}$ per acre. The harvesting and marketing cost was estimated at $\$ 2.00 / \mathrm{lb}$, whereas the fixed cost was $\$ 0.86 / \mathrm{lb}$. The total budgeted cost amounted to $\$ 3.38 / \mathrm{lb}$. Total operating costs were $\$ 7510.72 /$ acre, $\$ 1481.31 /$ acre, $\$ 1723.56 /$ acre, and $\$ 2092.20 /$ acre for years $1,2,3$, and
4 , respectively. Harvesting and marketing costs were $\$ 1040.25 /$ acre, $\$ 4137.88 /$ acre, and $\$ 8016.67 /$ acre for years 2, 3, and 4, respectively. Note that year 4 is assumed to be in full production. Total fixed costs were $\$ 2074.83$ /acre, $\$ 1170.42 /$ acre, $\$ 1206.76 /$ acre, and $\$ 3438.48 /$ acre for years 1, 2, 3, and 4, respectively. Recaptured establishment costs of $\$ 2176.43$ /acre were included in year 4 as part of fixed costs.

In year 3, phytophthora root rot control was the largest variable cost component, $\$ 384.78 /$ acre, equivalent to $22.3 \%$ /acre of total variable/ operating cost. However, chemicals 
Table 7. Estimated fourth-year establishment and maintenance cost per acre of producing southern highbush blueberries in soil in Georgia.

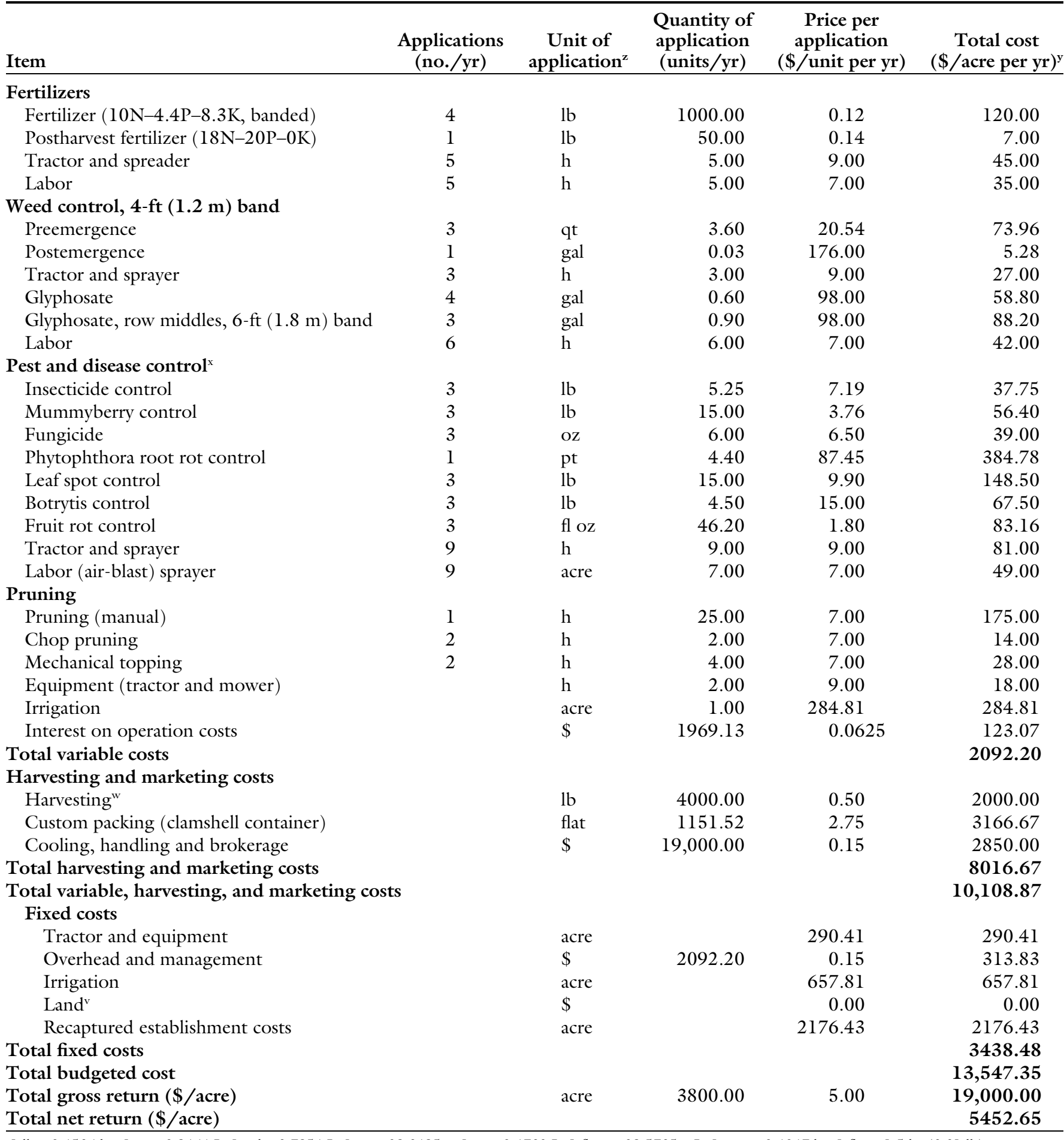

${ }^{\mathrm{z}} \mathrm{l} \mathrm{lb}=0.4536 \mathrm{~kg} ; \mathrm{l} \mathrm{qt}=0.9464 \mathrm{~L} ; \mathrm{l} \mathrm{gal}=3.7854 \mathrm{~L} ; \mathrm{l} \mathrm{oz}=28.3495 \mathrm{~g} ; \mathrm{l} \mathrm{pt}=0.4732 \mathrm{~L} ; \mathrm{l} \mathrm{fl} \mathrm{oz}=29.5735 \mathrm{~mL} ; \mathrm{l}$ acre $=0.4047 \mathrm{ha} ; \mathrm{l} \mathrm{flat}=1.5 \mathrm{~kg}(3.31 \mathrm{lb})$.

'Totals may not add up as a result of rounding error; $\$ 1.00 /$ acre $=\$ 2.4711 /$ ha.

${ }^{\times}$Mummyberry (Monilinia vacciniicorymbosi), phytophtora root rot (Phytophthora cinnamoni), leaf spot (Septoria albopuncata, Colletotrichum gloeosporioides, Gloeosporium minus), botrytis (Botrytis cinerea), fruit rot (Alternaria tenuissima, Colletotrichum gloeosporioides).

wWe assumed $95 \%$ packout rate.

vA typical price per acre varies significantly. Annual leasing price often range from $=60 /$ acre to $\$ 100 /$ acre

used for pest and disease control contributed to over $48.6 \%$ of total variable cost, equivalent to $\$ 837.94$ / acre. Total harvesting and marketing costs were $\$ 4137.88$ /acre.
Fixed machinery cost was $\$ 290.41 /$ acre and included sprayers, rotary mower, wagons, tractor, hedger, truck, spreader, mulcher, harrow, $\mathrm{V}$ blade, and charges for land. The total establishment costs for years 1,2 , and 3 were $\$ 9585.55 /$ acre, $\$ 3691.99 /$ acre, and $\$ 7068.20 /$ acre, respectively. After compounding at the fixed rate of $6 \%$ for the expected 20 -year 
Table 8. Risk-rated returns over total costs of producing southern highbush blueberries in soil in Georgia.

\begin{tabular}{|c|c|c|c|c|c|c|c|}
\hline Returns $(\$)^{\mathrm{z}}$ & \multicolumn{3}{|c|}{ Optimistic } & $\begin{array}{c}\text { Expected } \\
5456\end{array}$ & \multicolumn{3}{|c|}{ Pessimistic } \\
\hline Chances $^{\mathrm{y}}$ & $6 \%$ & $16 \%$ & $32 \%$ & $66 \%$ & $70 \%$ & $84 \%$ & $93 \%$ \\
\hline \multicolumn{3}{|c|}{ Chances for profit $=92 \%$} & \multicolumn{5}{|c|}{ Base-budgeted net revenue $=\$ 6,456$} \\
\hline
\end{tabular}

${ }^{2}$ Net return levels.

yThe chances of obtaining this level or more.

${ }^{x}$ The chances of obtaining this level or less.

lifespan of the farm under Georgia conditions, the annual recaptured establishment cost was $\$ 2176.43 /$ acre.

The annual fixed cost of solid set irrigation was estimated at $\$ 657.81 /$ acre and included pipe and fittings, sprinklers, 8-inch-diameter well capable of pumping $600 \mathrm{gal} / \mathrm{min}$, pump, motor, installation, and miscellaneous expenses. The variable/ operating cost component of the solid set irrigation was \$284.81/ acre, whereas the total annual costs (i.e., total operating cost plus total annual fixed costs) were \$942.62/ acre. Although the solid set system was relatively expensive in terms of initial investment per acre, it was necessary for spring frost and freeze control.

The expected yield for southern highbush blueberry in soil in Georgia was $4000 \mathrm{lb} /$ acre. If only $95 \%$ of the fruit is recovered in the field or during harvesting and packaging, and the expected price was $\$ 5.00$ / $\mathrm{lb}$, then the total return was $\$ 19,000.00 /$ acre. The risk-rated net returns showed that there was only a $6 \%$ chance of obtaining $\$ 15,140.00 /$ acre of southern highbush blueberry in soil in Georgia, whereas there was a $7 \%$ chance of earning a negative return of $-\$ 474.00 /$ acre. Furthermore, there were $66 \%$ chances of earning the expected $\$ 5456.00 /$ acre. The riskrated returns over total costs further depicted that the base-budgeted net revenue was $\$ 6456.00 /$ acre with a $92 \%$ chance of making a profit under Georgia conditions.

\section{Literature cited}

Abbe, D.S. and C.S. Messer. 2002. Agricultural prices. Official Georgia estimate-Blueberries. Census of agriculture Georgia profiles. 4 Nov. 2005. $<$ http://www.nass.usda.gov/ga/cropests/ bluebery.txt $>$.

Brigham, E.F. 1982. Financial management theory and practice. 3rd ed. Dryden Press, New York.

Brown, E. and R.E. Skinner. 1980. Economic analysis of selected sprinkler irrigation systems. Univ. Georgia Coop. Ext. Ser. Bul. 731.

Cline, B. and M. Mainland. 1999. Blueberry production recommendations and costs introduction, p. 9-12. In: Proc. 33rd Annual Open House. North Carolina Blueberry Council. Elizabethtown, NC.

Krewer, G. and D.S. NeSmith. 2002. The Georgia blueberry industry: Its history, present state and potential for development in the next decade. Acta Hort. 574:101-106.
Lisec, B., T. Cross, and B. Strik. 1995. Blueberry economics: The costs of establishing and producing blueberries in the Willamette Valley, Oregon State Univ. Ext. Serv. EM 8526.

Payne, J.A., A.A. Amis, R.J. Beshear, R.J. Gagne, D.L. Horton, and P.M. Lyrene. 1993. 'New' rabbiteye blueberry insects: Maggots, midges, thrips, and root weevils, p. 37-38. In: G. Krewer (ed.). Proc. 6th Biennial Southeast Blueberry Conf., Tifton, GA.

Pollack, S. and S. Perez. 2003. Fruit and tree nuts situation and outlook yearbook. Market and Trade Economic Division, Economic Research Service, U.S. Department of Agriculture, October, FTS2003.

Smith, B.J. 2003. Susceptibility of southern high bush blueberry cultivars to Phytophthora root rot and Botryosphaeria stem bight, p. 18-27. In: G. Krewer (ed.). Proc. Georgia-South Carolina Blueberry Conf., Savannah, GA.

Steck, G.J. and J.A. Payne. 1993. Blueberry maggot, Rhagoletis mendax (Diptera: Tephritidae), Entomol. Circ. No. 358, Florida Dept. Agriculture and Consumer Services, Division of Plant Industry, Gainesville.

Westberry, G.O., W.O. Mizelle, D. Stanaland, and G. Krewer. 1995. Economic analysis of producing commercial blueberries. Univ. of Georgia Ag-Econ. Bul. 95-040. 